\title{
Вплив визначення ступеня інтоксикації при перитоніті на результати лікування пацієнтів
}

\author{
О.О. Біляєва' ${ }^{1}$ І.В. Кароль ${ }^{1,2}$ \\ 'Національний університет охорони здоров'я України імені П.Л. Шупика, Київ, Україна \\ 2Комунальне некомерційне підприємство «Броварська багатопрофільна клінічна лікарня», Бровари, Україна
}

\begin{abstract}
Анотація. Мета: вивчити вплив визначення ступеня інтоксикації при перитоніті на результати лікування пацієнтів. Об'єкт і методи дослідження. У дослідження включено 265 хворих з перитонітом, які проліковані в хірургічному відділенні Броварської багатопрофільної клінічної лікарні протягом 2020 р.: чоловіків 141 (53,2\%), жінок - 124 (46,8\%). Результати. У 194 (73,2\%) пацієнтів Мангеймський індекс перитоніту був I (без летальних випадків), у 63 (23,8\%) - II (летальність - 1,6\%), у 8 (3,0\%) - III ступеня (летальність - 50,0\%). Виконання програмованих санацій черевної порожнини у пацієнтів із III ступенем Мангеймського індексу перитоніту дозволило знизити летальність у 2 рази порівняно з прогностичною. Висновки. Велике значення для перебігу перитоніту має синдром ендогенної інтоксикації, при прогресуванні якого виникає поліорганна недостатність. Тому дуже важливо прогнозувати перебіг перитоніту за допомогою різноманітних шкал, особливо АРАCHE II і Мангеймського індексу перитоніту, що дасть можливість вчасно обрати правильну лікувальну тактику.
\end{abstract}

Ключові слова: перитоніт, запалення, ендогенна інтоксикація, поліорганна недостатність.

\section{Вступ}

Запалення - універсальна реакція організму на вплив пошкоджувального чинника. За участю у запаленні мікроорганізмів процес набуває інфекційного характеру, при якому відбувається складна взаємодія макроорганізму з мікроорганізмами та додатковими чинниками зовнішнього середовища. Для вивчення складних процесів запалення оптимально підходить модель перитоніту.

Серед основних патогенетичних механізмів багатьох тяжких патологічних процесів, а також летальних випадків на перший план виступає ендогенна інтоксикація. Цей синдром посідає основне місце і в розвитку та прогресуванні перитоніту. Тому для вибору правильного методу лікування перитоніту необхідно вивчити патогенез ендотоксикозу, адже усунення джерела перитоніту та боротьба з інтоксикацією $€$ запорукою успішного лікування цієї категорії пацієнтів [1-3].

На рівень ендотоксикозу впливають стан імунної системи та біологічних бар'єрів, джерело ендогенної інтоксикації, механізми перенесення токсичних речовин в організмі, інгібування та виведення токсинів. Тому тяжкість стану хворих на перитоніт визначається рівнем ендогенної інтоксикації [4].

Синдром ендогенної інтоксикації - складний симптомокомплекс, що характеризується порушенням водно-електролітного обміну, макро- та мікроциркуляції, змінами в клітинах на ультраструктурному рівні. Зміни в організмі людини при перитоніті зумовлені дією токсичних речовин, таких як біологічно активні речовини в надмірній концентрації, продукти перекисного окиснення ліпідів (ПОЛ) та порушеного метаболізму, мікробні ендо- та екзотоксини. Основним джерелом токсинів при перитоніті $\epsilon$ очеревина та паретичний кишечник, що знаходяться в стані гіпоксії. Ендотоксини можуть бути первинними і вторинними. Первинними ендотоксинами при перитоніті виступають мікробні токсини, вторинними - продукти руйнації клітин [5].

Катаболізм білків $\epsilon$ джерелом токсинів на всіх рівнях катаболізму. Причиною цього $€$ активація системи ендогенного протеолізу з одночасним зниженням антипротеолітичної активності. У зону запального процесу мігрують гранулоцити і макрофаги, що виділяють протеїнази, яким відводиться основна роль у розвитку протеїназно-інгібіторного дисбалансу. При потраплянні макрофагів та гранулоцитів у вогнище запалення відбувається активація в них метаболічних процесів, що супроводжується дегрануляцією та руйнуванням клітин із вивільненням лізосомальних ферментів у позаклітинний простір [6].
У розвитку запалення на початковому етапі важливу роль відіграють нейтральні протеїнази, такі як еластаза, колагеназа та катепсин G, які чинять пошкоджувальний вплив на тканини у вогнищі запалення. На їх рівень також впливають бактеріальні ферменти. Лізосомальні ферменти забезпечують селективний протеоліз, який активує систему комплементу, калікреїн-кінінову систему та плазмову систему згортання і фібринолізу, в результаті чого утворюються фактори гемокоагуляції, біологічно активні пептиди, фактори калікреїн-кінінового каскаду і фібринолізу. Лізосомальні ферменти забезпечують неспецифічний протеоліз, який веде до інактивації та деградації інгібіторів протеїназ, плазмових білків, клітинних мембран і сполучної тканини [7].

Під час цих процесів протеолітичні системи забезпечують реутилізацію пошкоджених клітин при запаленні, тобто це $\epsilon$ компенсаторно-пристосувальною реакцією організму на пошкоджувальний чинник з формуванням гістіоцитарно-гематичного бар'єру. При відсутності цього бар'єру запалення поширюється на нові ділянки очеревини і відбувається масивне потрапляння у внутрішн $\epsilon$ середовище мікробних та некротичних токсинів і протеїнів. Прорив мікробних та лізосомальних протеїназ у кров'яне русло зумовлює «протеїназний вибух» при перитоніті. Ці ферменти активують екстрацелюлярну систему протеолізу, в результаті гіперактивності якої виникають гемодинамічні порушення, що можуть спричинити шок [8].

Лізосомальні протеїнази беруть участь у неспецифічному протеолізі і спричинюють деградацію структурних білків організму при перитоніті, внаслідок чого виникає білкова дистрофія, а в крові з'являється велика кількість продуктів білкового метаболізму - молекул середньої маси (МСМ) [9]. МСМ — група гетерогенних білкових молекул з масою 300-5000 Да та різноманітною структурою. До них належать глікопротеїди, нуклеопротеїди, олігопептиди, похідні спиртів і глюкуронових кислот, гуморальні регулятори, нуклеотиди. МСМ мають токсичні властивості: пригнічують фагоцитарну активність лейкоцитів, трансформацію лімфоцитів та зумовлюють розвиток імунодефіциту, чинять нейротоксичний вплив, сприяють гемолізу еритроцитів та пригнічують еритропоез, роз'єднують процеси тканинного дихання і окисного фосфорилювання, пригнічують синтез білка, підвищують проникність капілярів та викликають сладж [10].

На розвиток синдрому ендогенної інтоксикації значний вплив чинять продукти ПОЛ. При прогресуванні перитоніту наростає ендотоксикоз, виникає тканева гіпоксія й активується ПОЛ [8].

Патогенез перитоніту - складний процес взаємодії інфекційного чинника, патологічних реакцій організму на запальний про- 
цес та захисних сил організму. При перитоніті виникає наступний симптомокомплекс: запалення, біль, порушення цілісності органів черевної порожнини, парез кишечнику, порушення водно-електролітного та кислотно-основного обміну, інтоксикація, імуносупресія, порушення мікроциркуляції та гемодинаміки, тканинного дихання та розвиток поліорганної недостатності [5]. Синдром поліорганної недостатності включає гостру ниркову та печінкову недостатність, респіраторний дистрес-синдром, синдром дисемінованого внутрішньосудинного згортання, порушення функції центральної нервової системи. Важливу роль у виникненні поліорганної недостатності відіграє бактеріальна транслокація. Мікроорганізми з кишечнику через мезентеріальні судини та лімфатичні вузли потрапляють в загальний кровотік, чим зумовлюють розвиток сепсису та поліорганної недостатності [11].

Основним джерелом інтоксикації при перитоніті $\epsilon$ паретичний кишечник і запалена очеревина, що викликає розвиток ентеральної недостатності. Однією з причин ї̈ виникнення $\epsilon$ порушення моторної функції кишечнику. Пригнічують м'язову активність кишечнику токсини мікроорганізмів у вогнищі запалення. Також при перитоніті порушуються мікроциркуляція, системна гемодинаміка і метаболізм, що зумовлюють гіпоксію кишкової стінки. Це, в свою чергу, веде до порушення бар'єрної і транспортної функції кишечнику [10].

У розвитку синдрому ендогенної інтоксикації велику роль відіграє порушення бар'єрної функції тонкого кишечнику. Це зумовлюють зниження резистентності епітелію кишкової стінки, надмірна колонізація тонкого кишечнику мікроорганізмами та порушення фізіологічної цілісності слизової оболонки кишки [12].

Отже, ендотоксикоз в реактивній стадії перитоніту зумовлений руйнуванням клітин у вогнищі запалення, денатурацією білків, медіаторами запалення та мікроорганізмами. У період парезу кишечнику він виступає джерелом інтоксикації через порушення бар'єрної функції стінки кишки, розвиток дисбактеріозу та виникнення симбіотичного травлення, що веде до неповного гідролізу білків та утворення МСМ.

Враховуючи вищезазначене, тема дослідження $\epsilon$ актуальною. Мета дослідження: вивчити вплив визначення ступеня інтоксикації при перитоніті на результати лікування пацієнтів.

\section{Об'єкт і методи дослідження}

У дослідження включили 265 хворих із перитонітом, які проліковані у хірургічному відділенні Броварської багатопрофільної клінічної лікарні протягом 2020 р.: чоловіків - 141 (53,2\%), жінок - 124 (46,8\%). Захворювання, які стали причиною перитоніту: гострий апендицит - 177 (66,8\%), гострий холецистит $32(12,1 \%)$, перфоративна виразка шлунка або дванадцятипалої кишки - 23 (8,7\%), гострий деструктивний панкреатит - 6 $(2,2 \%)$, перфорація пухлини - 4 (1,5\%), перфорація тонкого кишечнику $-5(1,9 \%)$, травма черевної порожнини - 11 (4,2\%), дивертикулярна хвороба ободової кишки з перфорацією - 6 (2,2\%), тромбоз мезентеріальних судин - 1 (0,4\%) випадок.

\section{Результати}

При лікуванні хворих із перитонітом, окрім проведення інтенсивної терапії та хірургічного втручання, потрібно в найкоротший термін визначити тяжкість стану пацієнта і прогноз захворювання. Для цього існує велика кількість різноманітних шкал (АРАCHЕ I III, SAPS, SOFA, MODS, POSSUM, ALTONA, PIA, MPI та ін.), які часто конкурують між собою. На практиці найбільш поширеними у використанні $\epsilon$ шкали APACHE II (Acute Physiology and Chronic Health Evaluation) і Мангеймський індекс перитоніту (МІП) [13].

Але перед прогнозуванням перебігу захворювання варто розглянути структуру перитоніту в учасників дослідження.

Структура перитоніту за поширеністю процесу представлена в табл. 1. Найбільше відмічено випадків місцевого перитоніту - 144 (54,3\%).

У табл. 2 наведено розподіл пацієнтів із перитонітом залежно від стадії. У більшості пацієнтів $(53,6 \%)$ виявлена реактивна стадія перитоніту.
Характеристика перитоніту за характером ексудату в черевній порожнині представлена в табл. 3. Найчастіше ексудат в черевній порожнині був гнійним - у $76(28,7 \%)$ та серозним - у 75 (28,3\%) випадках.

Значного поширення при прогнозуванні перебігу перитоніту набув МІП, який запропонований у Німеччині ще в 1987 р. [14]. Перевага МІП в тому, що він розроблений для хворих на перитоніт. Фактори ризику хірург легко може визначити вже під час операції, що $\epsilon$ важливим при прогнозуванні перебігу захворювання. Тому в цьому дослідженні ми вирішили представити дані за МІП у пацієнтів, що проліковані у хірургічному відділенні з різноманітними нозологіями, ускладненими перитонітом.

У табл. 4 наведено величину МІП у пацієнтів залежно від нозології. У більшості пацієнтів (73,2\%) МІП був І ступеня. У 23,8\% пацієнтів визначали II, в 3,0\% - III ступінь МІП. Важливо відмітити, що в усіх пацієнтів із перфорацією пухлини МІП був ІІІ ступеня.

\section{Обговорення}

APACHE II - шкала оцінки гострих та хронічних змін, дозволяє визначити ризик летальності при перитоніті. В її основі лежить бальна оцінка фізіологічних і патологічних параметрів хворих. Автори розробили параметри, за якими можна підрахувати суму балів, які найбільш точно прогнозують розвиток захворювання. Але розрахунок показників за цією шкалою $\epsilon$ трудомістким і об'ємним у практичній роботі, а окремі показники $є$ доступними тільки для потужних лікувальних закладів [15].

Враховуючи той факт, що прогнозування перебігу захворювання за системою APACHE II не завжди можна зробити В перші години госпіталізації, ми запропонували модифікацію системи APACHE II, суттю якої $\epsilon$ визначення тих параметрів, які можна провести протягом 1-ї години госпіталізації. Ми частково

Таблиця 1 Структура перитоніту за поширеністю процесу

\begin{tabular}{lcc}
\hline & \multicolumn{2}{c}{ Кількість випадків } \\
\cline { 2 - 3 } & $\begin{array}{c}\text { Поширеність процесу } \\
\text { показник }\end{array}$ & $\%$ \\
\hline Місцевий & 144 & 54,3 \\
\hline Дифузний & 78 & 29,4 \\
\hline Розлитий & 29 & 11,0 \\
\hline Загальний & 14 & 5,3 \\
\hline Всього & 265 & 100 \\
\hline
\end{tabular}

Таблиця 2 Структура перитоніту залежно від стадії

\begin{tabular}{lcc}
\hline \multirow{2}{*}{ Стадія } & \multicolumn{2}{c}{ Кількість випадків } \\
\cline { 2 - 3 } & $\begin{array}{c}\text { Абсолютний } \\
\text { показник }\end{array}$ & $\%$ \\
\hline Реактивна & 142 & 53,6 \\
\hline Токсична & 110 & 41,5 \\
\hline Термінальна & 13 & 4,9 \\
\hline Всього & 265 & 100 \\
\hline
\end{tabular}

Таблиця 3 Структура перитоніту залежно від характеру ексудату

\begin{tabular}{lcc}
\hline \multirow{2}{*}{\begin{tabular}{l} 
Характер ексудату \\
\cline { 2 - 3 }
\end{tabular}} & $\begin{array}{c}\text { Кількість випадків } \\
\text { Абсолютний }\end{array}$ \\
\hline Серозний & 75 & 28,3 \\
\hline Серозно-фібринозний & 57 & 21,5 \\
\hline Фібринозно-гнійний & 37 & 13,9 \\
\hline Гнійний & 76 & 28,7 \\
\hline Каловий & 3 & 1,1 \\
\hline Геморагічний & 15 & 5,7 \\
\hline Жовчний & 2 & 0,8 \\
\hline Всього & 265 & 100 \\
\hline
\end{tabular}




\begin{tabular}{|c|c|c|c|c|}
\hline \multirow{2}{*}{ Нозологія } & \multicolumn{4}{|c|}{ MII } \\
\hline & Bcboro & І ступінь & ІІ ступінь & III ступінь \\
\hline Гострий апендицит & 177 & 132 & 45 & - \\
\hline Гострий холецистит & 32 & 25 & 7 & - \\
\hline Перфоративна виразка шлунка або дванадцятипалої кишки & 23 & 20 & 3 & - \\
\hline Перфорація пухлини & 4 & - & - & 4 \\
\hline Гострий деструктивний панкреатит & 6 & 3 & 2 & 1 \\
\hline Тромбоз мезентеріальних судин & 1 & - & - & 1 \\
\hline Перфорація тонкої кишки & 5 & 2 & 3 & - \\
\hline Травми черевної порожнини & 11 & 11 & - & - \\
\hline Дивертикулярна хвороба ободової кишки з перфорацією & 6 & 1 & 3 & 2 \\
\hline Всього & 265 & $194(73,2 \%)$ & $63(23,8 \%)$ & $8(3,0 \%)$ \\
\hline
\end{tabular}

обмежили деякі параметри системи APACHE II. У модифікованій оцінці визначали наступні параметри: артеріальний тиск, пульс, температуру тіла, частоту дихання, кількість лейкоцитів в периферичній крові, лейкоцитарний індекс інтоксикації, гематокрит, шкалу коми Глазго. Крім того, оцінювали у 4 бали наявність цукрового діабету, 5 - злоякісного новоутворення, 6 - ендотоксичного шоку.

Сумарна кількість балів за вказаними показниками в 1,72,1 раза менша, аніж кількість балів, запропонована авторами системи APACHE II. Наша модифікація системи APACHE ॥ об'єктивно і всебічно відображає тяжкість стану хворого. Для кожного параметра ми використовували найбільш аномальний показник за останні 24 год перед операцією чи перед оцінкою стану хворого. Якщо параметр не вимірювали, то його визнавали нормальним і оцінювали у 0 балів.

У нашій модифікації систему АРАCHE II використовували для оцінки тяжкості стану хворих із перитонітом, прогнозування перебігу захворювання та оцінки ефективності нових методів лікування хворих із перитонітом.

Таким чином, модифікована нами система APACHE II дозволяє досить точно і швидко визначити тяжкість стану пацієнта і спрогнозувати перебіг захворювання. Крім того, застосування цієї методики сприяє етіопатогенетичній оптимізації діагностичної та лікувальної тактики, стандартизації лікувальних заходів у пацієнтів із гострим перитонітом, та порівнянню ефективності цих заходів у рандомізованих групах пацієнтів.

МІП має високу чутливість, яка становить 83-98\% і зіставна із шкалою APACHE II. Головною перевагою МІП $\epsilon$ простота розрахунку, що дозволяє оцінити його результати вже під час операції та в будь-якому лікувальному закладі [15].

3 усіх 265 пацієнтів із перитонітом померли 5 (1,9\%), 3 них у 2 пацієнтів виявлено перитоніт, викликаний перфорацією пухлини, в 1 - мезентеріальним тромбозом, у 2 - деструктивним панкреатитом. У $4(80,0 \%)$ пацієнтів із летальним наслідком МІП був III, в 1 (20,0\%) - ІІ ступеня.

Серед 194 пацієнтів, у яких визначали I ступінь МІП, летальних випадків не зафіксовано. МІП II ступеня відзначений у 63 пацієнтів, з яких 1 (1,6\%) помер. 38 пацієнтів із III ступенем МІп відмічено 4 (50,0\%) летальних випадки. Схожі дані отримано іншими авторами, що вивчали цю проблему [13].

Наші дані дещо відрізняються від відповідних прогностичних показників МІП, але відмінність зміщена в бік більш позитивних фактичних показників порівняно з прогностичними, що підтверджує прогностичну значимість МІП. Ми погоджуємося 3 думкою авторів [15], що перевагами МІП $€$ простота застосування і можливість використання для ретроспективних досліджень.

Визначення МІП у пацієнтів стало передумовою застосування індивідуального підходу до лікувальної тактики та сприяло зниженню летальності, чим можна пояснити відмінність фактичних показників від прогностичних. Пацієнтам із III ступенем МІП виконували програмовані санації черевної порожнини, що дозволило знизити фактичну летальність у 2 рази порівняно 3 прогностичною.

\section{ВисновКИ}

1. У пацієнтів з І ступенем МІП летальність становила 0\%, 3 II - 1,6\%, 3 III - 50,0\%. Виконання програмованих санацій черевної порожнини у пацієнтів із III ступенем МІП дозволило знизити фактичну летальність у 2 рази порівняно з прогностичною.

2. Велике значення для перебігу перитоніту має синдром ендогенної інтоксикації, при прогресуванні якого виникає поліорганна недостатність. Тому дуже важливо прогнозувати перебіг перитоніту за допомогою різноманітних шкал, особливо АРACHE II і МІП, що дає можливість вчасно підібрати правильну лікувальну тактику.

\section{Інформація про внесок кожного учасника}

О.О. Біляєва - розробка концепції дослідження, визначення змісту та редагування статті; І.В. Кароль - збір матеріалу, написання статті.

\section{Конфлікт інтересів}

Автори, що взяли участь у цьому дослідженні, декларують відсутність конфлікту інтересів щодо цього рукопису.

\section{Згода на публікацію}

Всі автори дали згоду на публікацію цього рукопису.

\section{Фінансування}

Дослідження профінансоване коштом авторів.

\section{Список використаної літератури}

1. Beljaeva 0.A. (1999) Kompleksnoe lechenie peritonita i profilaktika ego oslozhnenij (jeksperimental'no-klinicheskoe issledovanie) [dissertacija]. Kiev, 375 s. [In Rus.].

2. Biliaieva 0.0., Kryzhevskyi V.V., Radzikhovskyi A.P. ta in. (2016) Laboratorna diahnostyka pry perytoniti ta ekonomichni aspekty likuvannia. Klinichna khirurhiia, 10(2): 10-12. [In Ukr.].

3. Biliaieva 0.0., Radzikhovskyi A.P., Kryzhevskyi V.V. ta in. (2011) Vybir khirurhichnoi taktyky pry rozpovsiudzhenomu perytoniti. Zbirnyk naukovykh prats spivrobitnykiv NMAPO imeni P.L. Shupyka, 20(1): 39-47. [In Ukr.].

4. Duzhyi I.D., Kravets O.V., Piatykop H.I. ta in. (2013) Dynamika kliniko-laboratornykh pokaznykiv endohennoi intoksykatsii u khvorykh z poshyrenym perytonitom. Akt. probl. suchasnoi medytsyny:Visnyk ukrainskoi medychnoi stomatolohichnoi akademii, 13(1):93-95. [In Ukr.].

5. Kyfiak P.V., Sydorchuk R.I., Khomko O.Y. et al. (2016) Carbohydrates metabolism in abdominal sepsis. The Unity of Science, 118-121 p.

6. Kyfiak P.V., Sydorchuk R.I., Khomko O.Y. et al. (2016) Metabolism of proteins and lipids in patients with abdominal sepsis. The Unity of Scienc;: 114-117 p.

7. Hacko V.V., Potapov V.V., Zenin 0.K. (2017) Jetiologija, patogenez i diagnostika sepsisa. Izvestija vysshih uchebnyh zavedenij. Povolzhskij region, 3(43): 139-150. [In Rus.].

8. Kryvoruchko I.A., Boiko V.V., Syvozhelizov A.V. (2012) Rozpovsiudzhenyi hniinyi perytonit. Halytskyi likarskyi visnyk, 19(3): 71-73. [In Ukr.].

9. Polianskyi I.lu., Maksymiuk V.V., Hrynchuk F.V. ta in. (2005) Totalna perytoneosorbtsiia yak metod sanatsii cherevnoi porozhnyny pry perytoniti. Shpytalna khirurhiiia, 4: 64-66. [In Ukr.].

10. Voitiv Y., Ulianivskyi V.S., Molokus I.V. (2015) Zminy deiakykh pokaznykiv endohennoi intoksykatsii pry riznykh stupeniakh porushen funktsii kyshok pry perytoniti. Molodyi vchenyi, 1(16): 146-148. [In Ukr.].

11. Hresko M.M., Hresko M.D. (2018) Imunolohichna reaktyvnist u khvorykh na hostryi perytonit. Art of medicine, 4(8): 48-51. [In Ukr.].

12. Benedykt V.V. (2013) Abdominalnyi sepsys u khvorykh na hostryi poshyrenyi perytonit. Shpytalna khirurhiia, 3:70-73. [In Ukr.]. 
13. Matviichuk O.B., Beshlei D.M., Kletsko L. ta in. (2010) Prohnostychne znachennia Manheimskoho indeksu perytonitu v suchasnii nevidkladnii abdominalnii khirurhii. Ukr. zhurn. khirurhii, 1: 110-113. [In Ukr.].

14. Linder M.M., Wacha H., Feldmann U. (1987) Der Mannheimer peritonitis-index. Ein instrument zur intraoperativen prognose der peritonitis. Chirurg, 58(2): 84-92.

15. Aksenova N.N., Ahmerov F.R., Maleev M.V. (2009) Manngejmskij peritoneal'nyj indeks v prognozirovanii posleoperacionnyh oslozhnenij u bol'nyh peritonitom. Obshhaja reanimatologija, 5(1): 32-36. [ln Rus.].

\section{The effect of determining the degree of intoxication in peritonitis on the results of treatment of patients}

\section{O.O. Bilyayeva ${ }^{1}$, I.V. Karol ${ }^{1,2}$}

'Shupyk National University of Health of Ukraine, Kyiv, Ukraine ${ }^{2}$ Brovary Multidisciplinary Clinical Hospital, Brovary, Ukraine
Abstract. Aim: to investigate the effect of determining the degree of intoxication in peritonitis on the results of treatment of patients. Matherials and methods. The study included 265 patients with peritonitis who were treated in the surgical department of Brovary Multidisciplinary Clinical Hospital during 2020: 141 (53.2\%) men and 124 (46.8\%) women. Results. In 194 (73,2\%) patients, the Mannheim peritoneal index was grade I, among them there were no fatalities, in $63(23.8 \%)$ patients the II (mortality was $1.6 \%$ ) and in $8(3.0 \%)$ patients - the III degree was determined (mortality was 50.0\%). Execution of programmed remediation of the abdominal cavity in patients with stage III Mannheim peritoneal index reduced the mortality by 2 times compared with the prognostic. Conclusions. Of great importance for the course of peritonitis is the syndrome of endogenous intoxication, the progression of which occurs multiorgan failure. Therefore, it is very important to predict the course of peritonitis using a variety of scales, especially APACHE II and the Mannheim peritoneal index, which allow to choose the right treatment tactics.

Key words: peritonitis, inflammation, endogenous intoxication, multiorgan failure.

\begin{abstract}
Відомості про авторів:
Біляєва Ольга Олександрівна — доктор медичних наук, професор кафедри загальної та невідкладної хірургії Національного університету охорони здоров'я України імені П.Л. Шупика, Київ, Україна. ORCID ID: 0000-0003-2862-0423

Кароль Іван Вікторович — кандидат медичних наук, асистент кафедри загальної та невідкладної хірургії Національного університету охорони здоров'я України імені П.Л. Шупика, Київ; лікар-хірург, лікар хірург-онколог КНП «Броварська багатопрофільна клінічна лікарня», Бровари, Україна. ORCID ID: 00000003-3684-0127
\end{abstract}

\author{
Адреса для кореспонденції: \\ Біляєва Ольга Олександрівна \\ 03680, Київ, просп. Любомира Гузара, 3 \\ E-mail: pr.bilyayeva@gmail.com
}

\section{Information about the authors:}

Bilyayeva Olga 0. - MD, Dr. Sc., Full Professor, Shupyk National University of Health of Ukraine, Department of General and Emergency Surgery, Kyiv, Ukraine. ORCID ID: 00000003-2862-0423

Karol Ivan V. - PhD, Shupyk National University of Health of Ukraine, Department of General and Emergency Surgery, Kyiv; Surgeon, Surgeon-Oncologist of Brovary Multidisciplinary Clinical Hospital, Brovary, Ukraine. ORCID ID: 0000-0003-3684-0127

\section{Address for correspondence:}

Olga Bilyayeva

03680, Kyiv, L. Guzar Ave, 3

E-mail: pr.bilyayeva@gmail.com 